Ви плідно несете це ім'я За Вашо участі і завдяки Вам вже проведено базато заходів із вшанування Вашого славного земляка, поширення о̆ого праць, виховання украінськоі свідомості. Нам приемно творчо співпрацювати з Вацим колективом. визначати шляхи подапьшого розвитку Українського православ'я на основі плідних ідей Арсена Річинського Віримо, чо ия співпраця буде продовжуватися. Хотілося $Б$ відтеорити постать Арсена Річинського у всій ī повноті. А відомо, що він залииив пом ітний

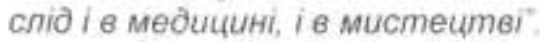

14 листопада 2006 року прах Арсена Річинського перевезено в Україну для перепоховання.

\title{
Використані джерела
}

1. Річинський А. Проблеми української релігійної свідомости. Володимир-Вопинський, 1933

2. Марчук В. Історичні нариси. Арсен Річинський: лікар і безкомпромісний патріот.// Лікарський вісник. Журнал українського лікарського товариства Північно Америки. - 4.1.- 2004.

\section{П. МАЗУР, Г. ГОЛУБ (Кременець) АРСЕН РІЧИНСЬКИЙ І ВИХОВАННЯ СТУДЕНТСЬКОІ МОЛОДІ}

В час національного відродження в Україні організація виховноі роботи у вищому навчальному закладі вимагає формування у студентів любові до рідноі землі, 6 історік. В час, коли до пюдей, які прагнуть пізнати правду про минуле, подинають повертатися діла тих, хто був поганьблений зумисним замовчуванням, найкраще це робити, вивчаючи історичні постаті кращих синів України, іх тернистий життевий шлях.

у 20-30-х роках минулого стопіття серед історичних діячів нашого народу одне 3 чільних місць посідає непересічна постать Арсена Річинського - лікаря за фахом громадського діяча за покликанням, ідеолога Українського Православ'я за етноконфесійними переконаннями.

Поряд із тим, Арсен Річинський у 20-30-х р. був організатором і керівником повітової управи пластунів. У праці під назвою "До щастя, слави і свободи" він писав: "Чи вдасться витворити нам сильні характери, 3 великим почуттям відповідальності, а заразом - сміливі, відважні, скорі в рішенню, енергійні в діланню - від того буде значною мірою залежатиме наша будучність" $(1,9)$ 
Присвоєння імені Арсена Річинського нашому навчальному закладу поставило перед колективом училища ряд завдань і дало нові можливості у вихованні студентів в дусі патріотизму

До дня підписання Постанови Кабінету Міністрів було виготовлено Прапор училища. Освячення । вручення Прапора відбулося у травні 1999 року. Свято відбулося біля пам'ятника Т.Г.Шевченку в День міста.

В музеї училища оформлено розділ, де діє фотовиставка про життєвий і творчий шлях Арсена Річинського, зберігаються оригінали рукописів наукових праць з медицини нашого земляка, копії ним написаних історій хвороб, рецептів, пистків непрацездатності та листів лікарських призначень, виписаних його рукою, ноти музичних творів авторства Арсена Річинського.

Виготовлення символіки, оформлення музею, створення фільму про Арсена Річинського сприяло тому, що в училищі відпрацьована ціла система виховної роботи, побудована на вихованні у студентської молоді гордості від того, що вони навчаються у навчальному закладі, який носить ім'я цього видатного українського патріота.

Однісї з особливостей медичної професії $є$ те, що працівник має свою форму - білий халат і косинку або шапочку Першого вересня традиційно відбувається урочиста лінійка з приводу свята Дня знань. Після того у першокурсників починається двохтрьохтижневий період навчання, коли ім не дозволяється одягати білий халат. За ці тижні в кожній групі відбуваються виховні години, де вивчається біографія Арсена Річинського, студенти знайомляться 3 його науковою і творчою спадщиною, відвідують музей училища, переглядають фільм "Арсен Річинський - ідеолог українського православ'я".

По закінченню знайомства першокурсників 3 історією училища, біографією । творчістю Арсена Річинського урочисто проводиться свято білого халата. Відбувається це, як правило, в районному будинку народної творчості, де збираються студенти і працівники училища, а також батьки першокурсників. Перед Державним Прапором України та Прапором Кременецького медичного училища студенти першокурсники приймають Присягу студента училища і ім вперше дозволяється одягнути символ медичного працівника - білий халат.

Пізніше студенти повертаються до вивчення біографіі і творчості Арсена Річинського на загальноосвітніх і клінічних предметах. За результатами наукових пошуків щорічно проводяться конференціі. Кращі роботи беруть участь у регіональних студентських читаннях серед вищих навчальних закладів |-|| рівнів 
акредитаціі Тернопілля. Засновано іменну стипендію Арсена Річинського, яка присвоюється кращим студентам навчального закладу, у бібліотеці училища оформлена виставка літератури про життя і діяльність Арсена Васильовича. Червоною ниткою у вихованні українського патріотизму проходить вислів А.Річинського, закарбований ним на сторінках своєі праці "Проблеми української релігійної свідомості": "Чим більше людина інтелектуально обдарована й розвинена, тим яскравіше і з більшою силою виступають особливості "/ національної вдачі. Тому геній завжди 3 психологічного боку є глибокою національним, і тільки люди розумом убогі, особливо недоумки та ідіоти, позбавлені національних прикмет" $(2,162)$.

Не менш урочисто відбувається вручення дипломів. Винуватці свята приймають присягу випускника медичного училища і урочисто прощаються з Прапором училища.

На всіх урочистостях студенти і викладачі виконують Гімн училища "Місто юності", написаний викладачем іноземних мов, кандидатом філологічних наук Анатолієм Янковим, у якому є слова:

Арсена Річинського славне ім'я

На прапорі нашому гордо сія.

Нев'янучі квіти у ранній росі -

Його милосердя і святість душі.

Важкливим виховним моментом було проведення в училищі у 2000 році Других Річинських читань, де було репрезеятовано перевидану головну книгу його життя "Проблеми української релігійної свідомості", а також проведення в червні 2002 року у містах Тернополі - Кременці - Володимир-Волинську Урочистої Академіі та Третіх Річинських читань, присвячених 110-й річниці з дня народження Арсена Річинського. На стіні навчального корпусу училища по вул. Словацького, 12 було відкрито меморіальну дошку, де золотими літерами викарбовано напис:

\section{Арсен Васильович Річинський 1892-1956}

Відомий український вчений - релігієзнавець, лікар, просвітитель, творець духовної музики, в'язень тоталітарних режимів 30-50pp.

В час національного та державного відродження українського народу розроблена система виховної роботи дозволяє виробити у студентів почуття патріотизму, любові та гордості за 
державу, місто і навчальний. заклад, де вони проживають і навчаються.

\section{Використані джерела}

1. Річинський А. Проблеми української релігійної свідомості. Тернопіль, 2002.

2. Річинський А. Проблеми української релігійної свідомості. Володимир-Волинський, 1933.

\section{Ю. ПАЄВСЬКИЙ (Червоноград) АРСЕН РІЧИНСЬКИЙ БУВ МОÏМ ХРЕСНИМ БАТЬКОМ}

Я людина дуже далека від питань релігієзнавства. Тому навіть не знаю, як перед такою солідною аудиторією тут виступати. Вийшло так в житті, що, як бачу, дуже відома людина, навіть я не знав те, що вона настільки відома, Арсен Річинський був моїм Хресним батьком. Родина Річинських і родина Паєвських (це прізвище моїх батьків) багато літ, десь з 20-х роках минулого століття, були як одна сім'я, тобто були в дуже добрих стосунках між собою, наскільки в добрих, що наведу для засвідчення цього приклад. Батько мій, Денис Паєвський, жив на Волині як емігрант 3 Радянського Союзу: в 20-х роках м.ст. він втік на Захід, а потім вернувся в Польщу. По спеціальності він був, як кажуть нині, бізнесмен. Коли він зібрав стартовий капітал і хотів відкрити свою фірму, то ще не мав польського громадянства. Тому свою фірму він відкрив, зареєструвавши ії на Річинського. Справа в тому, що в Польщі був якийсь часовий ценс, тобто стількись років треба було бути мешканцем цієї країни, щоб одержати право на відкриття своєї фірми.

Я Арсена Річинського фактично не пам'ятаю. Зрозуміло, щио немовля не могло щось запам'ятати, а коли його заарештували більшовики, то мені тоді не було ще й чотирьох років. Але знаєте, навіть в трьохлітньому віці все ж щось таке залишається в пам'яті. Іноді це просто якісь туманні спомини.. Наприклад, я пам'ятаю, що на день народження Річинський мені подарував шоколадного коня. Такого коня, як котеня маленьке. Той кінь був з гіркого шоколаду, не дуже може навіть і смачний, бо він був не з наповнювачами. Але на ньому була металева вуздечка. Знаєте, багато в сім'ї моїй з того, що було колись, не залишилось, а ось деякі дрібнички сімейні - мамині і батькові - та ще й кусочок тієї вуздечки залишилися. Ось він. Я вам показую. Ця вуздечка від іграшкового коника зберігалася у нас 50 років. Розумієте, тут не йшлося про цінність металу, з якого вона 